\title{
DOS CLÉRIGOS EN UNA FAMILIA DE OFICIALES REALES: NOTAS SOBRE FRANCISCO Y ANTONIO GARCÍA DE VILLALPANDO
}

\author{
ANA ISABEL CARRASCO MANCHADO ${ }^{1}$
}

\begin{abstract}
Resumen: En este artículo se analiza la carrera eclesiástica de dos clérigos, los hermanos Francisco Villalpando y Antonio García de Villalpando. Se estudia, asimismo, la influencia ejercida por sus familiares: su padre, Sancho García de Villalpando,contador mayor, oidor y consejero de la corte de Juan II; su tío, Ruy García de Villalpando, oidor de la audiencia real, y otros parientes que desempeñaron oficios de corte en la Casa de los reyes de la dinastía Trastámara, en Castilla y en Aragón. Se analizan, finalmente, los vínculos que dichos hermanos tuvieron con la alta nobleza (linaje de los Osorio y de los Velasco). Ambos clérigos -especialmente Antonio García de Villalpando, que era amigo del Cardenal Cisneros-, por su formación intelectual, su origen familiar y sus relaciones sociales, caracterizan un tipo de carrera eclesiástica.

Palabras clave: Familia García de Villalpando; Oficios de Casa y Corte; Casa de Trastamara; Clérigos.
\end{abstract}

Abstract: This study analyzes the ecclesiastical career of two clergymen, the brothers Francisco de Villalpando and Antonio García de Villalpando. It analyzes also the influence of its relatives: its father, Sancho García de Villalpando,contador mayor de cuentas of the king Juan II, oidor and royal counsellor; its uncle, Ruy García of Villalpando, oidor of the Royal Audience, and other relatives that had positions in the Royal Household and Court Trastámara, in Castille and in Aragon. It analyzes, finally, its linkings with the high nobility (lineage of the Osorio and the Velasco). Both clergymen - specially Antonio García de Villalpando, friend of Cardenal Cisneros-, by their intellectual formation, their family origin and their social relations, they caracterize a type of ecclesiastical career.

Keywords: García de Villalpando Family; Household and Court Trastamara; Clergymen.

'Departamento de Historia Medieval, Facultad de Geografía e Historia, Universidad Complutense de Madrid. 2005 .

Fecha de recepción del artículo: junio 2005. Fecha de aceptación y versión final: julio

«Anuario de Estudios Medievales», 35/2 (2005), pp. 605-633 .- ISSN 0066-5061. 


\section{SUMARIO}

1. Introducción.- 2. Orígenes familiares: los García de Villalpando, oficiales reales.- 2.1. Mi padre y los anteçesores dél.- 2.2. Mis tíos sus hermanos y los dependientes de su generaçión, en la su muy real e muy grande de Aragón.- 3. “Oficio y Beneficio”, estrategia familiar del contador mayor Sancho García de Villalpando.- 4. Francisco y Antonio García de Villalpando, clérigos.- 5. Conclusión: mentalidad "hidalga" y condición eclesiástica.

\section{INTRODUCCIÓN}

Desde hace un tiempo hemos venido investigando sobre el autor de un voluminoso tratado religioso-político titulado Razonamiento de las Reales Armas y dedicado a los Reyes Católicos, conservado en un único manuscrito de una biblioteca madrileña, una obra en la que apenas nadie había reparado hasta ahora. En el curso de la trascripción y estudio de dicha obra, identificamos al autor, cuyo nombre completo era Antonio García de Villalpando. Este autor aparecía en los repertorios bibliográficos de obras impresas asociado a una obra escrita para evangelizar a los moriscos, hoy desaparecida y que también ha creado bastante confusión ${ }^{2}$. Nada más se sabía de este raro escritor del siglo XV. Las primeras pistas para rastrear su biografía procedían del capítulo conclusivo del Razonamiento de las Reales Armas:

Demás de la natural obligaçión que commo su súbdito e vasallo a vuestras altezas devo, soy, allende desto, a servir deudor muy perpetuo e obligado, porque mi padre y los anteçesores dél, con ofiçios de letras y en el exerçiçio de las armas y de confiança grande, sirvieron en esta su muy real y muy grande Casa de Castilla, y otros mis tíos sus hermanos y los dependientes de su generaçión, en la su muy real e muy grande de Aragón, en el tienpo ya de muchos días pasado y agora, en el muy çercano a nuestros días, quando estavan presentes los muy grandes e muy poderosos prínçipes reyes e señores, nuestros señores, los reyes de memorias bienaventuradas e gloriosas, proginitores de vuestras magestades que

\footnotetext{
${ }^{2} \mathrm{La}$ identificación del doctor Antonio García de Villalpando como autor del Razonamiento de las Reales Armas de los Reyes Católicos, el mismo autor que figura asociado a la Instrucción para la vida cristiana, la hemos llevado a cabo en Ana Isabel CARRASCO MANCHADO, Antonio García de Villalpando: contribución a la biografía del autor del Razonamiento de las Reales Armas de los Reyes Católicos. «Memorabilia. Boletín de Literatura Sapiencial», 7 (2003), (http:// parnaseo.uv.es./Memorabilia/Memorabilia7/Carrasco.htm). Este estudio lo hemos realizado gracias a una Beca Postdoctoral de Caja Madrid (2002-2004).
}

«Anuario de Estudios Medievales», 35/2 (2005), pp. 605-633 .- ISSN 0066-5061. 
pasaron a la gloria, de cuyas magnifiçençias reales resçibieron muchas merçedes que oy en Castilla e en Aragón se conosçen y paresçen?.

Como tantos otros hombres de letras de su época, Antonio de Villalpando ponía su pluma al servicio de la reina Isabel y de su marido, sumándose así a una miríada de panegiristas, cuyo objetivo último era lograr el reconocimiento regio a esa labor. Pero esta declaración escrita tiene además su importancia al revelarnos su figura como un descendiente de una ramificada familia de oficiales de la Casa real trastámara, activa tanto en Castilla como en Aragón, familia que llevaba, a lo que parece, varias generaciones sirviendo en puestos de gran confianza junto a los reyes, en oficios de letras y de armas. Partiendo de esta pista y retrocediendo en el tiempo dimos con una familia de letrados, los García de Villalpando, que no parece haber despertado, hasta el momento, el interés de la historiografía, a pesar de haber ejercido, efectivamente, puestos de importancia en la administración real en el siglo XV, sobre todo en tiempos de Juan II. Nos ocuparemos ahora de resumir los datos que hasta la fecha hemos recogido de dos de sus miembros: los hermanos Francisco de Villalpando y Antonio García de Villalpando, ambos clérigos. Sus orígenes familiares y sus trayectorias comparten rasgos sociales comunes con una parte del clero de mediados del siglo XV.

\section{ORÍGENES FAMILIARES: LOS GARCÍA DE VILLALPANDO, OFICIALES REALES}

\section{1. «...Mi padre y los anteçesores dél»}

La Colección Salazar y Castro, de la Biblioteca de la Real Academia de la Historia, y algún otro legajo que guarda esta institución, aportan la información básica para identificar a la familia de los García de Villalpando, cuyo origen se sitúa en Tierra de Campos, entre Toro y Villalpando. El descendiente más remoto parece ser un tal García de Villalpando, afincado en Toro, que tuvo dos hijos: Ruy García y Francisco García. De este García de Villalpando no tenemos más datos que el que aparece en un árbol genealógico

\footnotetext{
${ }^{3}$ Biblioteca Lázaro Galdiano, Razonamiento de las Reales Armas de los Reyes Católicos, Ms. 768 , fols. $291 \mathrm{v}-292 \mathrm{r}$.

«Anuario de Estudios Medievales», 35/2 (2005), pp. 605-633 .- ISSN 0066-5061.
} 
trazado por Salazar y Castro ${ }^{4}$, en cambio, sí poseemos datos más concretos de sus dos hijos, Ruy y Francisco. Los dos hermanos, Ruy y Francisco, eran doctores y estaban vinculados durante la primera década del siglo XV con Juan Álvarez de Osorio, señor de Villalobos y de Castroverde. En 1417, el doctor Francisco García de Villalpando había fallecido ya, pero no así su hermano Ruy, que aparece como testamentario de Juan Álvarez de Osorio y como su alcalde mayor, oficio éste importante dentro de una casa señorial, pues conllevaba el gobierno del señorío en ausencia del señor y el ejercicio de la jurisdicción, razón por la cual solía corresponder a un letrado ${ }^{5}$. Nos interesa destacar, sin embargo, la figura de Francisco García de Villalpando, por ser el abuelo de los dos clérigos aquí estudiados. Este testamento nos aporta el nombre de la mujer y de los tres hijos del fallecido doctor Francisco García de Villalpando, es decir, el nombre de la abuela y de los que serán padre y tíos de los clérigos Francisco y Antonio:

\begin{abstract}
Otrosí ordeno y mando que Constanza Fernández, muger que fue del doctor Francisco García de Villalpando, que Dios perdone, e los fijos del dicho doctor y della, es a saber, Diego García, bachiller en Decretos y Sancho y Rodrigo, los quales aprenden estudio en Salamanca, que ayan y tengan del dicho Pedro Alvar Osorio mi fijo el Molino que dicen de Palacio, situado en el término de la dicha villa de Castroverde, en el río que llaman Val de Rue (Valderaduey), contra la puerta de la dicha villa que llaman la Puerta del Pozo del Molino, que aya y tenga el dicho molino del dicho Pedro Alvar de Osorio mi fijo, según y en la manera que ella y los fijos del dicho doctor de mi lo tiené
\end{abstract}

De los tres hijos del doctor Francisco García, es su hijo Sancho el que será identificado como padre de los clérigos Francisco y Antonio. En 1417, Sancho García de Villalpando se encontraba, por tanto, estudiando en Salamanca con sus otros dos hermanos, bajo el amparo y protección de Juan Álvarez de Osorio, abuelo éste del primer marqués de Astorga. Así pues, hay que vincular a los primeros miembros de esta familia con el linaje de los

${ }^{4}$ Biblioteca de la Real Academia de la Historia (RAHB), Ms. 9/300, fol. 17 r., $2^{\text {a }}$ fol.

${ }^{5}$ En el testamento de Juan Álvarez de Osorio aparece citado dos veces: como testamentario (fol. 302 v.) y en la siguiente manda dirigida a su hijo Pedro Álvarez de Osorio: «Otrosí ordeno y mando que el doctor Ruiz García de Villalpando, que sea alcalde del dicho Pedro Álvarez Osorio, mi fijo, en toda su tierra, según y en la manera y con los despachos y condición que ahora es mi alcalde maior» (RAHB, Ms. 9/928, fol. 301 v).

${ }^{6} \mathrm{RAHB}, 9 / 928$, fol. $306 \mathrm{r}$.

«Anuario de Estudios Medievales», 35/2 (2005), pp. 605-633 .- ISSN 0066-5061. 
Osorio. Un hecho a destacar es que, ya en estas fechas, la fidelidad de la familia se encontraba repartida entre el servicio a una casa noble y el servicio en la corte y casa real: Francisco García de Villalpando, caballero avecindado en Toro, doctor en Decretos, figura como oidor de la audiencia real y del consejo ${ }^{7}$. El hermano de éste, llamado Ruy García de Villalpando, al que hemos identificado como el alcalde mayor de Juan Álvarez de Osorio, tuvo también un hijo homónimo que aparece en la documentación como «licenciado» Ruy García de Villalpando ${ }^{8}$, también vecino de Toro. En este punto hay que llamar la atención sobre una circunstancia que ha venido confundiendo a aquéllos que han recopilado datos sobre esta familia, que es la tendencia a repetir los nombres de pila de generación en generación, tendencia tan frecuente en la época y que provoca la existencia de numerosos homónimos, en este caso, homónimos de nombre Ruy García de Villalpando, Francisco de Villalpando, Diego de Villalpando o Sancho García de Villalpando. Es fácil confundir al doctor Ruy García de Villalpando, alcalde mayor que vivía en 1417, con su hijo, el licenciado Ruy García de Villalpando, y a estos dos con un sobrino y primo ${ }^{9}$ de ambos, respectivamente, que, como veremos, también será doctor, el doctor Ruy García de Villalpando. El licenciado Ruy García del que hablamos llegó también a ser oidor de la audiencia real y del consejo desde $1446^{10}$, y seguía siéndolo en $1455^{11}$. Parece ser el mismo que fue enviado con funciones de asistente a Sevilla por Enrique $\mathrm{IV}^{12}$. En el grado de

\footnotetext{
${ }^{7}$ Así figura en una carta de donación suscrita por su nieto, Juan de Villalpando, «hijo del honorable señor Ruy García de Villalpando, doctor en decretos, hijo del honorable señor Francisco García de Villalpando, discreto doctor en decretos, oidores de la sacra audiencia del serenísimo señor rey de Castilla y sus consejeros». Copia de Salazar y Castro de la carta fechada en Zaragoza, el 14 de junio de 1447 (RAHB, Ms. 9/815, fols. 200v-201r). Ver también, RAHB, Ms. 9/300, fol. 17r, $2^{\text {a }}$ fol.

${ }^{8}$ RAHB, Ms. 9/300, fol. 17, $2^{\text {a }}$ fol.

${ }^{9} \mathrm{El}$ licenciado Ruy García de Villalpando figura como testamentario de su primo, el doctor Ruy García de Villalpando, en el codicilo que éste otorgó en Toro, el 6 de mayo de 1455 (RAHB, $9 / 829$, fols. $125 v-126)$.

${ }^{10}$ Archivo General de Simancas (AGS), Patronato Real, leg ${ }^{\circ} 7, \mathrm{n}^{\circ}$ 109: juramento de fidelidad que hizo el licenciado Ruy García de Villalpando a Juan II.

${ }^{11}$ Se menciona al «licenciado Rui García de Villalpando, oidor de la dicha abdiencia del dicho Señor Rey e del su consejo, vecino de la dicha cibdat de Toro», en RAHB, Ms. 9/829, fol. $126 \mathrm{r}$.

${ }^{12}$ En 1458 Enrique IV envió a Sevilla al licenciado Ruy García de Villalpando con órdenes especiales y con el mandato de que, si no acudían los veinticuatro y jurados de Sevilla a la corte que residía en Jaén, que los prendiese y embargase sus bienes (Árchivo Histórico Nacional -AHN-, Sección Nobleza, Frías, caj. 9, docs. 17 y 18).

«Anuario de Estudios Medievales», 35/2 (2005), pp. 605-633 .- ISSN 0066-5061.
} 
parentesco familiar con los dos clérigos Francisco y Antonio se sitúa entre los primos del padre de ambos, el doctor Sancho García.

Esto es todo lo que sabemos del abuelo y tío-abuelo de los dos clérigos aquí tratados. En cuanto al padre de ambos, recordemos que su nombre figuraba en el testamento de Juan Álvarez de Osorio ya mencionado: Sancho García, que se hallaba estudiando en Salamanca en 1417 junto a sus dos hermanos, el bachiller en decretos, Diego García y su hermano Ruy (Rodrigo). En no mucho tiempo se convirtió en doctor, como sus otros dos hermanos, su padre y su tío, hecho a destacar, pues revela el interés de esta familia por conseguir, dentro de la carrera letrada, el más alto nivel universitario. Sin lugar a dudas, esta sólida formación universitaria contribuyó a proporcionarles a todos ellos oficios destacados en la administración real, ligados al ejercicio de la jurisdicción y a las finanzas.

El doctor Sancho García de Villalpando se casó con Constanza Núñez de Toledo ${ }^{13}$. Existe numerosa documentación sobre los cargos que ejerció, sus bienes, y sobre su vinculación con otro linaje noble, los Velasco, en especial con el primer conde de Haro, Pedro Fernández de Velasco. En 1435 Sancho García aparece ya como oidor de la audiencia real, recibiendo ocho escusados por tal oficio, por muerte del oidor Diego, obispo de Ávila ${ }^{14}$. Ese mismo año de 1435 le vemos intervenir como juez árbitro en un pleito entre el conde de Haro, Pedro Fernández de Velasco, y los herederos del judío Yuçaf el Nasçi, arrendador de las albaquías, por ciertas deudas que contrajeron los padres del conde, Juan de Velasco y María Solier, con el mencionado arrendador y con Ruy Fernández de Peñalosa. El pleito duró tres años y se falló en contra del conde, quien se vio obligado a pagar al tesorero real de las rentas de las albaquías, Abraham Bienveniste, 600.000 mrs. Durante todos esos años, el doctor Sancho García de Villalpando actuó sucesivamente como juez árbitro, como testigo en el pleito y como fiador del conde, comprometiendo para ello sus propios bienes ${ }^{15}$. Por aquellos años, el doctor Sancho García era ya contador mayor de cuentas. A lo que parece, el doctor Sancho García utilizó su influencia ante el rey como contador mayor para ayudar al conde a pagar

\footnotetext{
${ }^{13}$ Su nombre y el de su hijos (Francisco, arcediano de Mayorga, doña Marina, Diego, Juan y Antonio de Villalpando) aparecen en varios documentos relativos a la herencia del doctor, que falleció en 1473 (RAHB, Ms. 9/808, fol. 282 r.).

${ }^{14}$ AGS, Mercedes y Privilegios, $\operatorname{leg}{ }^{0} 1$, fol. 648 r.

${ }^{15}$ La documentación sobre este pleito en José Antonio García LuJÁN, Judios de Castilla (siglos XIV-XV). Documentos del Archivo de los duques de Frías, Córdoba, 1994, docs. 47-52.

«Anuario de Estudios Medievales», 35/2 (2005), pp. 605-633 .- ISSN 0066-5061.
} 
sus deudas ${ }^{16}$. El agradecimiento del conde no se hizo esperar. La sentencia de este pleito se había producido ya en mayo de 1438, y unos meses más tarde, Pedro Fernández de Velasco donaba al doctor el lugar de Toldanos, en León, mediante carta fechada en Santo Domingo de Silos, el 10 de julio de 1438. Entre las razones que justifican la donación no se halla ninguna de orden económico, aunque no hay que descartar que tenga alguna relación con las deudas del conde. Este documento es interesante para concretar otros aspectos de la vinculación política y personal del doctor Sancho García con el conde de Haro. En el preámbulo, en el cual aparece el doctor Sancho García como «contador mayor de las rentas del rey nuestro señor e su oidor e refrendario y del su consejo», se dice que el motivo de la donación fue,

\begin{abstract}
Haberlo acompañado dicho don Sancho en los grandes trabajos que el conde obo sobre la libertad del rey nuestro señor contra el rey don Juan de Nabarra, y contra el infante don Enrique, su hermano, y otros caballeros y grandes que tenían preso o detenido por fuerza a dicho rey en Tordesillas y en la batalla que el príncipe don Enrique, hijo del rey, hubo con don Juan de Navarra, cerca de la villa de Pampliega, en la que se halló el dicho Doctor con sus armas y caballo, cerca del referido conde, a quien acompañó hasta que el rey fue libre, y posteriormente en el real contra la villa de Peñafiel, rebelada por gentes de Don Juan de Navarra, la qual fue saqueada por dicho señor príncipe y posteriormente en la batalla campal cerca de Olmedo entre los dichos, donde fueron vencidos el rey de Navarra y infante don Enrique, por cuyas razones, habiéndose expuesto el doctor Sancho muchas veces a grandes peligros por la persona del conde, por vía de remuneración le hizo donación irrebocable entre vivos de los suelos, casas, poblaciones y por poblar, pechos, tributos, rentas y derechos que le pertenecían en el lugar de Toldanos, y sus términos, con la jurisdicción alta y baja, civil y criminal, mero mixto imperio y con todo lo poco o mucho que le pertenecía, podía o debía pertenecer en el dicho lugar y sus términos, lo que poseía por herencia de don Juan de Velasco y doña María de Solier, sus padres ${ }^{17}$.
\end{abstract}

Así pues, el doctor Sancho García, que había estudiado bajo el amparo de los Osorio, ascendió en su carrera gracias a la protección del conde

\footnotetext{
${ }^{16}$ Es lo que sugiere algún documento otorgado por el conde («Otrosí que se obligó el dicho dotor Sancho Garçía de me dar çiertas cartas del dicho señor rey de libramientos, libradas en mí en los recabdamnientos que por el dicho señor rey tove el año que pasó de mille e quatroçientos treinta e nueve años, en quantía de diez mill maravedís, de los quales levó mi carta de pago para en cuenta de la dicha abenençia», ibídem, doc. 55). El conde terminó de pagar su deuda en 1440.

${ }^{17}$ RAHB, Ms. 9/4450, no 18, fol. 1 r.-v. (copia simple). El lugar de Toldanos lindaba con San Martín de Valderaduey, que se encontraba ya en posesión del doctor Sancho García.
} 
de Haro. Esto no era de extrañar, habida cuenta de que Villalpando pertenecía al señorío de la casa de Haro. El doctor Sancho García era vecino en Villalpando, villa en torno a la cual fue ampliando su patrimonio. En esta villa poseía además derechos de patronazgo sobre el convento de San Francisco y otras iglesias ${ }^{18}$. La donación de Toldanos al doctor coincide, además, con una época especialmente conflictiva del reinado de Juan II. El doctor Sancho García intervino activamente junto al conde de Haro en el episodio del «Seguro de Tordesillas». En la narración histórica coetánea que se ha conservado de este episodio aparece Sancho García citado junto al conde de Haro como «un doctor suyo». En todo el proceso actuó como testigo de muchos de los juramentos y homenajes que se llevaron a cabo por las distintas partes, siempre al lado del conde de Haro, que lo nombró alcalde de casa y corte en la villa de Tordesillas, en virtud del poder otorgado por el propio rey ${ }^{19}$. Durante los años siguientes, el doctor Sancho García continuó prestando numerosos servicios al conde de Haro hasta la muerte de éste: intervino como testigo en la venta de la villa de Villaverde que Diego de Avellana hizo en beneficio de Pedro Fernando de Velasco, en $1440^{20}$; en 1449 recibió el pleito homenaje de Álvaro de Luna en el contrato que firmó con el conde de Haro para el matrimonio de sus hijos, y también recibió otros homenajes que el mismo condestable tuvo que prestar en el marco de ciertas confederaciones que concertó con el conde ${ }^{21}$. La estrecha vinculación con Pedro Fernández de Velasco quedó reflejada en el testamento que otorgó el conde el 14 de abril de 1458, en el Hospital de la Vera Cruz, según el cual manda a su hijo y heredero que haga del doctor Sancho García de Villalpando, «aquella cuenta y mención que es razón y sus servicios a esta casa adebdan, y de su consejo se faga aquellas cosas que cerca lo contenido en este mi testamento y de las otras cosas que al dicho don Pedro mi fijo tocaren y cumplieren se ovieren a facer, y aya del dicho don Pedro en cada año lo que agora de mí ha y le

${ }^{18}$ RAHB, Ms. 9/4450, $\mathrm{n}^{\circ} 18$, fol. 6 r.

${ }^{19} \mathrm{Su}$ intervención en el Seguro de Tordesillas en: El Seguro de Tordesillas, ed. Nancy F. Marino, Valladolid, 1992, pp. 62, 63, 64, 73, 95, 156-157, 188 y 190.

${ }^{20}$ Elisa Álvarez Llopis; Emma Blanco CAMPos; José Ángel GarCía DE CoRTÁZAR, Documentación medieval de la Casa de Velasco referente a Cantabria en el Archivo Histórico Nacional, sección nobleza, t. II, Santander, 1999, doc. 221.

${ }^{21}$ Firmadas en Valladolid, los días 11 y 12 de noviembre de 1449: Ester GoNZÁLEZ CRESPO, Elevación de un linaje nobiliario castellano en la Baja Edad Media: los Velasco, Madrid, 1981, doc. 73 y 74. Al año siguiente, el rey le ordena entregar al conde de Haro una carta por la que anulaba cualquier confederación que hubiera realizado con Álvaro de Luna, el marqués de Villena y el príncipe Enrique (AHN, Sección Nobleza, Frías, Caj. 1, doc. 24). 
procure del dicho señor Rey todos los veneficios y mercedes que podrá, pues es tal que continuando lo que fasta aquí siempre fizo, lo sabrá servir y

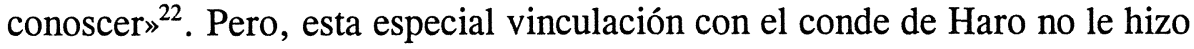
descuidar al contador mayor su relación con otros nobles: siguió manteniendo relaciones con los Osorio ${ }^{23}$, cuyo radio de influencia señorial se encontraba también en esa zona de Tierra de Campos; en 1442 compró de Diego López de Zúñiga y de Leonor Niño, su mujer, las villas de Berzosa y Fuentebureba, que, junto con Villamizar, adquirida por compra al convento de Santa Clara de Villafrechos en 1454, constituía la parte más importante de su patrimonio $^{24}$. Tras la muerte del conde de Haro, le vemos relacionado con Beltrán de la Cueva, recién nombrado conde de Ledesma ${ }^{25}$.

Por lo que respecta a sus oficios en la administración regia, hay que decir que el doctor Sancho García de Villalpando ejerció como oidor de la audiencia real desde, al menos, $1435^{26}$ y como contador mayor de cuentas, al menos desde 1439-144027, aunque algún autor ha sugerido la posibilidad de que participara en el ordenamiento de 1437 para la reforma de la Contaduría Mayor de Cuentas ${ }^{28}$. En 1464 consiguió renunciar el oficio de contador mayor de cuentas en uno de sus hijos, Juan de Villalpando, a pesar de que los

${ }^{22}$ Testamento de Pedro Fernández de Velasco, conde de Haro (copia simple), RAHB, Ms. $9 / 899$, fol. $261 \mathrm{v}$.

${ }^{23}$ García de Osorio, hijo de Pedro Álvarez de Osorio maestresala del rey, vendió al doctor Sancho García de Villalpando el lugar de San Martín de Villárdiga, según documento fechado el 15 de septiembre de 1444 (AHN, Sección Nobleza, Frías, Caj. 528, doc. 18).

${ }^{24}$ RAHB, Ms. 9/808, fol. 282 r. (noticia de la compraventa de Berzosa y Fuentebureba). Sobre la adquisición de Villamizar en 1454, AHN, Sección Nobleza, Osuna, Caj. 3.923, doc.1.

${ }^{25}$ El doctor Sancho García de Villalpando, junto con García Méndez de Badajoz, secretario real, tomó posesión de la villa de Ledesma con poder del conde Beltrán de la Cueva. Éste se encontraba con el rey en Madrid, el 22 de marzo de 1462, y hasta allí acudieron los procuradores de Ledesma para que el nuevo señor les jurara unos capítulos. El conde prestó homenaje en manos del doctor Sancho García (Alberto MARTín EXPósito; José María MONSALVO ANTÓN, Documentación medieval del Archivo municipal de Ledesma, Salamanca, 1986, doc. 86).

${ }^{26}$ Sancho García aparece ya como oidor de la audiencia, sustituyendo al oidor Diego, obispo de Ávila, por fallecimiento de éste (AGS, Mercedes y Privilegios, $\operatorname{leg}^{\circ} 1$, fol. 648).

${ }^{27}$ AGS, Quitaciones de Corte, leg $^{\circ}$ 1, fol. 269 (asiento de 26.666 mrs. de quitación y 1.733 para un oficial al doctor Sancho García de Villalpando, contador mayor de las cuentas para 1440 y adelante, por renuncia de Diego Román) y leg ${ }^{\circ} 4$, fols. 555-558, libranzas de 1456 a 1459.

${ }^{28}$ Cristóbal EsPEJO, Antecedentes de la Contaduría mayor de Cuentas hasta las Ordenanzas de 1478, «Boletín de la Sociedad Castellonense de Excursiones», VIII (1910), 92, p. 479, n. 1 y p. 481 , n. 2.

«Anuario de Estudios Medievales», 35/2 (2005), pp. 605-633 .- ISSN 0066-5061. 
procuradores habían solicitado al rey, repetidamente, que redujera el número de sus contadores y que se fueran extinguiendo algunos de los ya existentes ${ }^{29}$.

2.2. «Mis tios sus hermanos y los dependientes de su generaçión, en la su muy real e muy grande de Aragón»

Antonio de Villalpando, buscando el favor de Isabel y de Fernando, recordaba en su Razonamiento de las Reales Armas que también sus tíos y sus primos habían servido en la Casa Real aragonesa. Sin duda, el que se decía capellán real a la altura de 1487 pretendía aprovechar sus circunstancias familiares para halagar también al rey Fernando de Aragón. ¿Quién mejor que él, que procedía de una familia de servidores reales a las dos casas Trastámara, podría mostrar una fidelidad mayor a los titulares de esta doble monarquía castellano-aragonesa?

Los datos sobre estos miembros de la familia García de Villalpando, servidores en Aragón, se refieren a dos hermanos del doctor Sancho García de Villalpando, Diego y Rodrigo (Ruy), y también al hijo de éste último, Juan de Villalpando. De los tres hermanos García de Villalpando, Diego García de Villalpando debía ser el hermano mayor, pues ya figuraba como bachiller en decretos por Salamanca en 1417, en el mencionado testamento de Juan Álvarez de Osorio. Salazar y Castro le sitúa en la genealogía de esta familia como «chanciller y del consejo del rey Alfonso V de Aragón ${ }^{30}$. El segundo hermano del doctor Sancho García, tío de nuestros clérigos Antonio y Francisco, el doctor Ruy García de Villalpando, debió tener una vida bastante más agitada que la que tuvo su hermano pequeño, pues le vemos moverse entre los dos reinos, en Aragón y en Castilla. En la administración castellana ejerció el oficio de oidor de la audiencia real, al menos entre los años 1426 y $1435^{31}$. En 1446 seguía todavía cobrando como oidor de la audiencia rea ${ }^{32}$. Ruy García de Villalpando era, además, regidor en la villa de Toro. En fecha indeterminada parece ser que tuvo que huir al reino de Aragón, a causa de un asesinato cometido siendo regidor de Toro. El rey de Aragón lo acogió en su

\footnotetext{
${ }^{29} \mathrm{AGS}$, Quitaciones de corte, $\operatorname{leg}{ }^{\circ} 3$, fols. $702-706, \operatorname{leg}^{\circ} 1$, fol. 267. Sobre la renuncia en su hijo: Cristóbal ESPEJO, ibídem, p. 483.

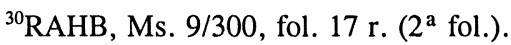

${ }^{31}$ RAHB, Ms. 9/805, fol. 270 v. y 9/812, fol. 55 v.

${ }^{32}$ AGS, Mercedes y Privilegios, leg $^{\circ} 1$, fols. 178, 179, 180, 592, 613, 620.

«Anuario de Estudios Medievales», 35/2 (2005), pp. 605-633 .- ISSN 0066-5061.
} 
servicio y le otorgó mercedes, a él y a sus hijos. Ruy García había tenido dos hijos de un primer matrimonio con Catalina Rodríguez: Francisco y Juan. El primogénito, Francisco, participó en la batalla de Ponza, en 1435, pero fue su segundo hijo, Juan de Villalpando, el que recogió el fruto de los servicios en la Casa real aragonesa, ya que sobrevivió a su hermano mayor, muerto ya en 1455. El doctor Ruy García fue consejero de Juan II, rey de Navarra y de Aragón, y su mismo hijo, Juan de Villalpando, ostentó el cargo de maestresala del rey ${ }^{33}$. En 1447, Ruy García otorgó una escritura de fundación del mayorazgo de Estopiñán, en el condado de Ribagorza, a favor de su hijo Juan de Villalpando ${ }^{34}$. Esta escritura está otorgada en la villa de Toro, lo cual quiere decir que Ruy García volvió a Castilla. Al parecer, las relaciones entre padre e hijo no fueron buenas y, en su lecho de muerte, en 1455 , el doctor Ruy García anuló algunas de las donaciones hechas a su hijo ${ }^{35}$. Su hijo Juan de Villalpando, señor de Estopiñán, siguió sirviendo al rey de Aragón hasta el punto de convertirse en mayordomo y consejero real y obtener numerosas mercedes y otros señoríos en tierras de Gerona ${ }^{36}$. Pero los datos sobre esta rama aragonesa y sus circunstancias vitales se vuelven confusas, debido a la existencia de otros homónimos de la misma familia, tal y como hemos advertido. Cesáreo Fernández Duro afirma que este Juan de Villalpando, hijo del doctor Ruy García, fue ahorcado por Juan de Ulloa en Toro ${ }^{37}$. Se trata de un episodio mencionado por dos veces por el cronista Fernando del Pulgar ${ }^{38}$.

${ }^{33}$ RAHB, Ms. 9/815, 199 v.-201.

${ }^{34}$ RAHB, Ms. 9/815, fols. 201 v. -203 v.

${ }^{35}$ «Por quanto él me a seido mucho desagradescido, e aunque me vio en gran menester y nescesidat ansí para mi provisión e mantenimiento, como para otras cosas a mi honra y estado nescesarias, sobre lo qual fue de mi parte requerido, él nunca me quiso socorrer ni honrrar nin ayudar nin comprió nin mantuvo lo quél era tenudo de facer e complir segúnd e en la manera que comigo puso»; codicilo firmado en Toro, 6 de mayo de 1455 (RAHB, Ms. 9/829, fols. 125v126r, copia).

${ }^{36}$ Casó con Contesina de Funes y añadió a sus señoríos la baronía de Quinto. Sus herederos consiguieron de Carlos I, en 1518, el ansiado privilegio de nobleza. A partir de entonces, y con el correr de los siglos, consiguieron entroncar, en el siglo XVIII, con Cristóbal Portocarrero, conde de Montijo. Todos estos datos sobre la historia del linaje de los Villalpando aragoneses están recogidos en Duque de BERWICK Y DE ALBA, Noticias históricas y genealógicas de los estados de Montijo y Teba, Madrid, 1915, pp. 256-258.

${ }^{37}$ Cesáreo FERNÁNDEZ DURO, Colección bibliográfico-Biográfica de noticias referentes a la provincia de Zamora. Madrid, 1891, p. 559.

${ }^{38}$ «Certificos, señor, que podría bien affirmar que los juezes no ahorcan oy un ombre por justicia por ningún crimen que cometa en toda Castilla, aviendo en ella asaz que lo merescen, como quier que algunos se ahorcan por injusticia. Dígolo porque poco ha que Juan de Ulloa en Toro enbió a las casas del licenciado de Valdivieso e de Juan de Villalpando, e los ahorcó de sus 
Posiblemente se tratase de Juan de Villalpando, como se ha afirmado, si se tiene en cuenta que su padre, el doctor Ruy García, pertenecía a la oligarquía de Toro, emparentado por vía matrimonial con otras familias de la oligarquía, los Deza y los Sosa ${ }^{39}$. También se a atribuido a este Juan de Villalpando algunos versos que aparecen recogidos bajo ese nombre en el Cancionero de Estúñiga, versos que encajan con la agitada vida de este personaje, primo de los clérigos Francisco y Antonio de Villalpando $0^{40}$.

\section{3. "OFICIO Y BENEFICIO”, ESTRATEGIA FAMILIAR DEL CONTADOR MAYOR SANCHO GARCÍA DE VILLALPANDO}

El contador mayor de Juan II, el doctor Sancho García de Villalpando, estaba casado con Constanza Núñez de Toledo (llamada también Catalina, en algunos documentos) y tuvieron, al menos, seis hijos: Juan, Francisco, Marina, Mencía, Diego y Antonio. El nombre de todos ellos, salvo el de Mencía, aparece en un documento sobre la herencia del doctor Sancho García, que en 1473 ya había fallecido ${ }^{41}$. No es extraño comprobar cómo los hijos del

puertas. Estos eran de los más principales de la ciudad" (Fernando del PULGAR, Letras, ed. Michael L. Dangerfield, Madison, Hispanic Seminary of Medieval Studies, 1992, Carta al Deán de Toledo escrita el 16 de junio de 1479). De este Juan de Villalpando dice que era «cauallero enparentado e onbre de façión" (Crónica de los Reyes Católicos, I, ed. Juan de Mata Carriazo, Madrid, 1943, p. 116).

${ }^{39}$ Su hija Catalina se casó con Martín de Sosa (RAHB, 9/829, fols. 125 v.-126 r.), que parece ser regidor de Toro, y su hija María García se casó con Alfonso de Deza (RAHB, $9 / 815$, fols. $199 \mathrm{v}-201 \mathrm{r}$.). El mismo doctor Ruy García estaba casado en segundas nupcias con María de Deza (RAHB, 9/815, fols. 197 v.-199 r.). Sobre el regimiento de Toro en la segunda mitad del siglo XV ver, José Ignacio MORENO, El regimiento de Toro en el siglo XV, «En la España Medieval», 7 (1985), pp. 773-783. No hemos confirmado la noticia del asesinato atribuido al doctor Ruy García.

${ }^{40}$ «Todo el mundo é trastornado/ mas nunca pude fallar/ Gutierre, con grand cuydado,/ franqueza que andáys buscar. / Siete annos puede aver /que de Castilla partí /solamente por veer /franqueza que nunca vi; /con la pobreza é topado /muchas vezes syn dubdar, /Gutierre, con grand cuydado, /franqueza que andáys buscar. / Sennor Gutierre de Argüello, /fuerte enpresa avéys tomado; /a mí mucho pesa d'ello, /mas, pasado como é pasado /tanto tiempo que he buscado /esa uirtud syngular, /Gutierre, con grand cuydado, /franqueza que andáys buscar. /Tanbién quiero que sepades /otra cosa que busqué: /gentileza, mas creades /que tanpoco la fallé; /buscándola, soy barbado /con muy terrible pesar, /Gutierre, con grande cuydado, / franqueza que andáys buscar». Cancionero de Estúniga, ed. Nicasio Salvador, Madrid, Alhambra, 1987, pp. 300-302.

${ }^{41}$ Convenio entre Constanza Núñez de Toledo y sus hijos, 6 de marzo de 1473, RAHB, Ms. 9/808, fol. 282r-v. AHN, Sección Nobleza, Osuna, Caj. 4.453, doc. 176: Carta de los hijos del doctor Sancho García de Villalpando a los lugares de Berzosa y Fuentebureba para que tengan por señora a su madre, Constanza Núñez de Toledo.

«Anuario de Estudios Medievales», 35/2 (2005), pp. 605-633 .- ISSN 0066-5061. 
doctor Sancho García se repartieron entre las dos vías posibles de mantenimiento y ascenso social que se les abrían: el oficio regio y la carrera eclesiástica: Juan y Diego continuaron con oficios de letrados y Francisco y Antonio se hicieron clérigos. Marina se casó con Francisco de Luzón ${ }^{42}$ y Mencía profesó en el convento de Santa Clara de Tordesillas ${ }^{43}$.

Juan de Villalpando, posiblemente el hijo mayor, primo de su homónimo aragonés, sucedió en la Contaduría Mayor de Cuentas a su padre, cuya renuncia se produjo el 21 de septiembre de 1464 . Desde 1452 venía ya cobrando quitación como guarda del rey, oficio que mantuvo durante el reinado de Enrique IV, así como el de doncel y escribano de las rentas del Infantadgo de Valladolid ${ }^{44}$. El hijo del doctor Sancho García aparece citado como contador mayor de cuentas en $1476 \mathrm{y}$, a lo largo del reinado de los Reyes Católicos, siguió ejerciendo algún puesto en la contaduría, ya que su nombre aparece en relación con el cobro de la Santa Cruzada, en $1500^{45}$. No obstante, su estado no parece verse aumentado a lo largo de su vida, a pesar de su oficio en la administración. Ello quizá fuera debido a su vinculación con Enrique IV. Isabel y Fernando mantuvieron a muchos de los oficiales del rey Enrique IV, pues esta continuidad les proporcionaba legitimidad, pero sólo premiaron con especiales mercedes a sus colaboradores más leales, tal y como se refleja, por ejemplo, en la trayectoria de Gutierre de Cárdenas, contador mayor de los Reyes Católicos. De la herencia de su padre, Juan de Villalpando recibió el señorío de Berzosa y Fuentebureba, la parte principal de su patrimonio, pero esta herencia le fue discutida por los propios vecinos de dichos lugares, ya que, en torno a 1485 , inician un pleito con su señor, alegando su pertenencia al Condado de Vizcaya y, por tanto, a la Corona, pleito que termina ganando Juan de Villalpando ${ }^{46}$. Una posible ayuda real en

${ }^{42}$ Cesáreo FERNÁNDEZ DURO, ob. cit., p. 558-559.

${ }^{43}$ En 1461 , Mencía de Villalpando, ya era monja profesa de dicho convento (Jonás CASTRO TOLEDO, Colección diplomática de Tordesillas, Valladolid, 1981, doc. 700.

${ }^{44}$ Todos estos datos en AGS, Quitaciones de Corte, leg $^{\circ}$ 3, fols. 702-706, leg ${ }^{\circ}$ 1, fol. 267 y Cámara de Castilla, leg $^{\circ} 30$.

${ }^{45}$ Aparece citado como contador en un documento extractado por Salazar y Castro, fechado el 10 de noviembre de 1476, sobre la donación, a la muerte de su padre, de los lugares de Berzosa y Fuentebureba por su hermano Francisco, que a su vez lo había recibido en donación de su hermano Antonio (RAHB, Ms. 9/808, fol. 282r.). Su relación con la recaudación de la Santa Cruzada, el 28 de octubre de 1500. Archivo de la Real Chancillería de Valladolid -AChV-, Registro de Ejecutorias, Caj. 152, 37.

${ }^{46}$ Véase, entre otros documentos, la carta real AGS, $R G S, 10$ de diciembre de 1489, fol. 166

«Anuario de Estudios Medievales», 35/2 (2005), pp. 605-633 .- ISSN 0066-5061. 
este pleito parece ser el principal favor que recibió de los reyes, además del mantenimiento de sus oficios. En 1505 ya había fallecido Juan de Villalpando, pues su viuda, Catalina de Torquemada, toma posesión de su herencia en esa fecha $^{47}$.

El segundo hermano de Francisco y de Antonio que siguió oficio de letras fue Diego de Villalpando. De él tenemos menos datos. Sabemos que fue colegial de San Bartolomé, en Salamanca, el año $1459^{48}$, sin embargo, no nos arriesgamos a identificarlo con el Diego de Villalpando que aparece como rector por el turno de León en el Libro del Claustro de la Universidad de Salamanca los años 1467-1468 ${ }^{49}$, aunque bien pudiera ser el mismo. También hay cierta confusión en torno a este Diego de Villalpando, originada por los múltiples homónimos que pueblan la descendencia de esta familia ${ }^{50}$ : recordemos que su tío, servidor de los Trastamara aragoneses, también se llamaba Diego de Villalpando. El hijo del contador mayor se encontraba en 1469 en Villalpando, villa desde la que suscribe un documento ${ }^{51}$. Hay también noticias sobre un Diego de Villalpando corregidor de Astorga por el marqués, en $1494^{52}$, que podría ser un posible familiar suyo, si tenemos en cuenta la vinculación de los García de Villalpando con los Osorio. Conocemos además a un Diego de Villalpando, escribano de cámara, que ejerce al menos hasta 1504 , fecha en la que recibe una receptoría de la Chancillería de Valladolid ${ }^{3}$.

${ }^{47} \mathrm{El} 1$ de diciembre de 1502 , RAHB, Ms. 9/808, fol. 282r. Los hijos de ambos pleitearán por la herencia hasta varios años después, 1508 (AChV, Registro de Ejecutorias, Caj. 226, $\operatorname{leg}^{\circ} 2$ ).

${ }^{48}$ José RojaS, Historia del colegio de San Bartolomé, I, Madrid, 1766, p. 174.

${ }^{49}$ F. MARCos, Extractos de los libros de claustro: siglo XV. Salamanca, 1964, $\mathrm{n}^{0} 295$.

${ }^{50} \mathrm{La}$ entrada biográfica de C. FERNÁNDEZ DURO, ob. cit., p. 558, incluye errores ya apuntados por Rojas (al que cita), como el atribuir a este Diego de Villalpando un comentario sobre la Partida VII (Lectura solemnis et Repetitio Legis XXII. Tit. I. Partitae VII. De pacto seu transactione super delictis celebranda, impresa en León, en 1552). Este autor homónimo del siglo $\mathrm{XVI}$ podría tratarse de un nieto del hijo del contador mayor.

${ }^{51}$ El 9 de junio de 1469: Diego de Villalpando, hijo del doctor Sancho García, contador mayor de cuentas del rey, y de su consejo, otorga y conoce que recibe del deán y cabildo de la iglesia de León, la renta de la tercia de Cerecinos, aldea de Villalpando (César ÁlvarEZ FERNÁNDEZ, Colección documental del Archivo de la Catedral de León (1351-1474), XII, León, 1995, doc. 3.863).

${ }^{52}$ AGS, RGS, 1494-05-25, fol. 350. Medina del Campo: Seguro a favor de Luis Flores, vecino de Villamañán, que teme del marqués de Astorga y de Diego de Villalpando, corregidor en la citada villa.

${ }^{53}$ Quitación como escribano de cámara en AGS, Quitaciones de Corte, $\operatorname{leg}^{\circ}$ 1, fol. 9; la receptoría otorgada a Diego de Villalpando, "nuestro escribano", el 26 de febrero de 1504, AGS, Consejo de la Cámara de Castilla - CCA-, Libros Registro de cédulas -CED-. Libros generales de la Cámara, Libro, 9,43 , doc. 1. 
Estos dos homónimos no pueden ser el hijo del contador mayor Sancho García, pues contamos con la fecha de su muerte. En 1493 ya había fallecido Diego de Villalpando, hijo del contador mayor Sancho García de Villalpando, según declara su hijo en una solicitud de copia de su testamento firmada en Villalpando, el 1 de marzo de 1492. El hijo de Diego se llamaba igual que su abuelo, Sancho García de Villalpando ${ }^{54}$ y podría identificarse con un Sancho García de Villalpando que figura en 1498 como secretario de la princesa Margarita ${ }^{55}$. Sea como fuere, éste último también tuvo un hijo de nombre Diego, fruto de su matrimonio con María de Baeza ${ }^{56}$, su hijo mayor, y figura como escribano en 1532, en un documento sobre la venta al Condestable del lugar de San Martín y de Toldanos, lugares que procedían del patrimonio del contador mayor ${ }^{57}$. ¿Podría tratarse éste del mismo Diego de Villalpando que recibió la receptoría de la Chancillería de Valladolid en 1504?

Dejando a un lado la confusión que suscitan todos estos familiares y descendientes del contador mayor Sancho García, de todas estas notas que hemos podido recopilar queda al menos clara la dedicación de todos ellos a los oficios de letras, preferentemente desempeñados en la Casa Real. Son muchos menos los García de Villalpando que se orientaron al clero, pero alguno de ellos, a pesar de no conseguir ningún obispado, sí logró cierta notoriedad, gracias a su proximidad con el Cardenal Cisneros y a las obras que dejó escritas. Nos referimos a Antonio García de Villalpando, cuya trayectoria y la de su hermano, trazaremos brevemente.

\footnotetext{
${ }^{54}$ En RAHB hay un legajo completo dedicado a la descendencia de Diego de Villalpando, hijo del contador Sancho García, de quien heredó el lugar de Toldanos y de San Martín (Ms. 9/4450, $\operatorname{leg}^{0} .2, n^{\circ}$ ). Se casó con María de Vaca (o Cabeza de Vaca) y tuvo, además de a Sancho, a otros hijos: Francisco García de Villalpando, María, Catalina, Constanza, Brianda e Isabel.

${ }^{55} \mathrm{AGS}, R G S, 22$ de diciembre de 1498, fol. 29: El Consejo Real (desde Ocaña) al corregidor de Arévalo para que no consienta que se pida yantar a Sancho García de Villalpando, secretario de la princesa doña Margarita, en razón de la merced de una escribanía pública de dicha villa, dada por la reina madre doña Isabel, ya que no había usado dicho oficio, y si algo le han llevado por concepto de tal yantar, se lo restituyan.

${ }^{56}$ RAHB, Ms. 9/4450, leg ${ }^{0} 2, n^{\circ} 4$, Testamento de Sancho García de Villalpando, otorgado el 24 de octubre de 1504 en Villalpando.

${ }^{57}$ Luis Calvo Lozano, Historia de Villalpando y su tierra, Zamora, 1981, p. 378.
}

«Anuario de Estudios Medievales», 35/2 (2005), pp. 605-633 .- ISSN 0066-5061. 


\section{Francisco y ANTONIO GARCÍA DE VILLALPANDO, CLÉRIGOS}

El primero de los hijos del contador mayor Sancho García de Villalpando que se orientó hacia la carrera eclesiástica fue Francisco de Villalpando. Su actividad está ligada, sobre todo, al reinado de Enrique IV, pues su trayectoria en época de Reyes Católicos se difumina bastante. Se le ha localizado como clérigo en la diócesis de Sigüenza, canónigo de Astorga, canónigo de Palencia en 1458, capellán real, arcediano de Mayorga y canónigo de León, arcediano de Carrión desde 1480 y, en 1484, arcediano de Cerrato $^{58}$. Nos interesa destacar su vinculación con la capilla real de Enrique IV desde $1457^{59}$, vinculación que puede atribuirse a su parentesco con el contador mayor del rey. Igualmente se percibe la influencia familiar en la posesión de los otros beneficios y dignidades: su canonjía en Astorga habría que ponerla en conexión con las relaciones que mantenía la familia del contador con los Osorio, ya apuntadas al inicio de este trabajo. Hay que tener en cuenta que desde 1440 hasta 1463 era obispo de Astorga Álvaro de Osorio, cuyo padre, Juan Álvarez de Osorio, había ayudado al futuro contador mayor Sancho García y a sus hermanos a estudiar en Salamanca. Curiosamente, Francisco de Villalpando ya no era canónigo de Astorga en 1464, sino que había "ascendido" a provisor del obispado de León, coincidiendo con los años en que Álvaro de Osorio pierde el obispado de Astorga ${ }^{60}$. La posesión del arcedianato de Mayorga, en el obispado de León, posiblemente se relacione también con su padre, ya que éste disfrutaba en 1454 de un juro sobre las alcabalas de Sant Herbás, lugar dependiente de Mayorga, juro que empleó para la compra de Villamizar al convento de Santa Clara de Villafrechos ${ }^{61}$. No es ésta la única relación del contador con los conventos de la zona, pues se

\footnotetext{
${ }^{58}$ Toda esta información, recogida por José Manuel NIETO SORIA, Iglesia y génesis del Estado Moderno en Castilla (1369-1480). Madrid, 1994, p. 464.

${ }^{59}$ Libranzas de 1457-1462 a Francisco de Villalpando, canónigo de León y Astorga, hijo del doctor Sancho García de Villalpando, como capellán del rey: AGS, Quitaciones de Corte, $\operatorname{leg}^{\circ} 3$, fols. 218-219. Asiento de $5400 \mathrm{mrs}$ de ración a Francisco Villalpando capellán del rey, canónigo en las iglesias de León y Astorga, hijo del doctor Sancho García de Villalpando, por renuncia de Martín Ferrández Puertocarrero, $\operatorname{leg}^{\circ} 1$, fol. 261. José Manuel NIETO SORIA, La Capilla Real castellano-leonesa en el siglo XV: constituciones, nombramientos y quitaciones, "Archivos Leoneses", 85-86 (1989), pp. 7-54.

${ }^{60}$ César Álvarez FERnÁNDEZ, Colección documental, doc. 3.798.

${ }^{61} \mathrm{AHN}$, Sección Nobleza, Osuna, Caj. 3.923, doc. 1. Mayorga era también zona de influencia de los Osorio.
}

«Anuario de Estudios Medievales», 35/2 (2005), pp. 605-633 .- ISSN 0066-5061. 
sabe que parte del lugar de Toldanos se la compró al monasterio de San Claudio $^{62}$. Por otra parte, podría tenerse en cuenta además la relación que mantenía el contador mayor con los Cabeza de Vaca, familia asentada también en la zona de Tierra de Campos, con presencia en Toro y en León, importante familia de la oligarquía leonesa que llegó incluso a proporcionar un obispo, Pedro Cabeza de Vaca, obispo de León entre 1448 y $1459^{63}$. La relación con esta familia se refleja en el concierto del matrimonio de su hijo Diego de Villalpando con María Cabeza de Vaca ${ }^{64}$. El arcediano de Mayorga y canónigo de León tendría como cuñada a un miembro de esta familia.

En torno a 1464 Francisco de Villalpando logró alcanzar gran autoridad en el obispado de León, ya que aparece, no sólo como arcediano de Mayorga, sino como provisor general en todo el obispado de León. Esto es algo que tendrá en común con su hermano, el doctor Antonio García de Villalpando, que será, como veremos, provisor en el obispado de Osma. La profesión letrada compartida por tantos miembros de la familia, así como sus oficios relacionados con la práctica de la justicia, llevaron a los dos hermanos a desarrollar también tareas judiciales y de gobierno dentro de la Iglesia. En estos años centrales del reinado de Enrique IV alcanza la cima de su carrera ${ }^{65}$, las mismas fechas en las que participaba, posiblemente, en la vida de la corte en calidad de capellán real, desarrollando una vocación cortesana más que religiosa, ya que cabe atribuirle unos atrevidos versos que parodian en clave amorosa los Salmos Penitenciales ${ }^{66}$. En tiempos del reinado de los Reyes Católicos parece conservar su vinculación con la Casa real, pues hay datos sobre pagos de quitaciones atrasadas de 1499 a 1501 a Mosén Francisco de

${ }^{62}$ RAHB, Ms. 9/4450, $\operatorname{leg}^{0} 6, \mathrm{n}^{\circ} 1$. Los monjes de San Claudio de León venden al doctor García de Villalpando el barrio llamado de la "Orden" en Toldanos, a cambio de $8 \mathrm{mil} \mathrm{mr}$. situados en la alcabala del vino extranjero (León, 8 de enero de 1449).

${ }^{63}$ Sobre esta familia, José María SANTAMARTA LuENGOS, Señorío y relaciones de poder en León en la Baja Edad Media (concejo y cabildo catedral en el siglo XV), León, 1993, pp. 86-89.

${ }^{64}$ María Cabeza de Vaca, hija de Nuño Fernández Cabeza de Vaca y de Brianda de Vega; véase nota 54 y RAHB, Ms. 9/1541.

${ }^{65}$ Rastros documentales en César ÁlvarEz FERNÁNDEZ, ob. cit., docs. 3805, 3798.

${ }^{66}$ Valentín NÚÑEZ RIVERA, Glosa y parodia de los Salmos Penitenciales en la poesía de cancionero, «Epos. Revista de Filología», 17 (2001), pp. 132-135. Los versos fueron atribuidos por Nicasio Salvador a Francisco de Villalpando, el hermano fallecido de Juan de Villalpando, señor de Estopiñán y servidor de los reyes de Aragón, llevado por la coincidencia de nombres y por el hecho de que también este Juan de Villalpando escribió poesía de cancionero (Nicasio SALVADOR, La poesía cancioneril. El Cancionero de Estúniga, Madrid, 1977, pp. 258-260). Los versos pueden leerse en Cancionero castellano del s. XV de la Biblioteca Estense de Módena, ed. Marcella Ciceri, Salamanca, 1995, pp. 192-193.

«Anuario de Estudios Medievales», 35/2 (2005), pp. 605-633 . - ISSN 0066-5061. 
Villalpando ${ }^{67}$. Su muerte podría ser fechada antes de 1508 , si es que su nombre se identifica con un clérigo llamado "Villalpando" mencionado en el conocido poema de Francisco de Ávila, La vida y la muerte ${ }^{68}$.

La carrera eclesiástica de Antonio García de Villalpando, el autor del Razonamiento de las Reales Armas, siguió un ritmo distinto a la de su hermano Francisco. Las palabras dirigidas a los reyes que recogimos al principio de este trabajo nos indican que su carrera estaba comenzando al llegar el reinado de Isabel y de Fernando y hasta el término del reinado no conseguirá su mayor cota de influencia en el arzobispado de Toledo. Antonio sería el menor de los hijos del contador mayor, y la muerte de su padre, en 1473 , le privó de una posible ayuda, aunque bien es verdad que los tiempos habían cambiado: el reino se hallaba dividido durante la guerra por la sucesión, y, tal y como hemos sugerido, no parece que la familia del contador mayor de Juan II y de Enrique IV fuera de las más leales a la causa isabelina. Sin desdeñar sus circunstancias de partida y los lazos de clientela que ampararon a sus familiares (los Osorio, los Velasco...), Antonio tuvo que fortalecer su acercamiento a los nuevos monarcas, tal y como hemos destacado, y para ello utilizó su formación intelectual, regalando a los reyes el Razonamiento de las Reales Armas, una obra original que exaltaba la nueva monarquía dual a partir de un entramado propagandístico que podía ser utilizado además como material legitimador. Pero esto ocurría a mediados de los años ochenta del siglo XV.

Aunque quizá contara con menos apoyos personales que le impulsaran en su ascenso, su trayectoria vital no deja de tener estrecha relación con su extracción social, y lo vemos reflejado en su formación intelectual, en su posición dentro de la Iglesia, en las actuaciones que llevó a cabo, en su talante personal incluso, y en su vida privada. En cuanto a su formación, alcanzó el mayor grado universitario, el de doctor, grado que, como hemos visto, llevaban ostentando varios miembros de su familia durante, al menos, tres

\footnotetext{
p. 537.

${ }^{67}$ Cuentas de Gonzalo de Baeza, II, ed. A. de la Torre y E. A. de la Torre, Madrid, 1955,

${ }^{68}$ «Todos pruevan mi xarope /sin saber cómo ni quándo ${ }_{2} /$ de Valladolid fray Lope, /Villanueva, Villalpando /obedecieron mi mando»; Francisco de ÂVILA, La vida y la muerte o Vergel de discretos, ed. Pedro Cátedra, Salamanca, 2000, p. 325.

«Anuario de Estudios Medievales», 35/2 (2005), pp. 605-633 .- ISSN 0066-5061.
} 
generaciones. No tenemos constancia segura de su paso por la Universidad de Salamanca, pero hay indicios que apuntan a que fue asi ${ }^{69}$.

Los beneficios y dignidades que obtuvo guardan cierto paralelismo con los que tuvo su hermano Francisco. A Antonio García de Villalpando lo encontramos citado primero como arcediano de Ledesma, entre 1473 y $1476^{70}$. Antes de la redacción del Razonamiento de las Reales Armas, no encontramos mención alguna segura relativa a su vinculación eclesiástica, salvo su propia declaración de que es capellán real. La redacción de esta obra se sitúa entre 1480 y 1487 . Parece lógico pensar que fue su hermano, Francisco de Villalpando, también capellán real, quien introdujo a su hermano en la corte ${ }^{71}$. Hasta 1491 no le encontramos citado como el doctor Antonio García de Villalpando ${ }^{72}$. Entre 1484 y 1487 hay datos sobre un «licenciado Villalpando» que ejerce como visitador general de las Inquisiciones, quien, por encargo de Tomás de Torquemada, inspeccionaba un tribunal especial que se instauró en esas fechas para la zona de Medina del $\mathrm{Campo}^{73}$. ¿Podría tratarse de Antonio García de Villalpando, antes de conseguir el grado de doctor? Dada su formación intelectual, bien podría tratarse de él, teniendo en

${ }^{69} \mathrm{En} 1469$, aparece un tal Álvaro de Villalpando, bachiller, al que se le concede una cátedra cursatoria en leyes, en sustitución del titular, el doctor Diego Rodríguez de San Isidro (Vicente BELTRÁN DE HEREDIA, Cartulario de la Universidad de Salamanca, II, Salamanca, 1970-1973, p. 225). Podría tratarse de Antonio, si consideramos que hemos detectado frecuentes errores en la transcripción de su nombre de pila, cuando éste aparece abreviado como $A^{o}$ (En Antonio MATIlla TASCón, Declaratorias de los Reyes Católicos, sobre reducción de juros y otras mercedes. Madrid, 1952, p. 232, por ejemplo, aparece un Álvaro de Villalpando que pierde las tercias de Berzosa y Fuentebureba, tercias que correspondían a Antonio de Villalpando, por su padre). En 1470, hay una noticia de la compra de un Digesto nuevo comprado por la Universidad de Salamanca al bachiller Villalpando, al precio de $3.100 \mathrm{mrs}$ (Vicente BELTRÁN DE HEREDIA, ob. cit., t. II).

${ }^{70}$ Aparece así citado en las noticias extractadas por Salazar relativas al traspaso de la herencia del contador mayor Sancho García de Villalpando (RAHB, Ms. 9/808, fol. 282r).

${ }^{71}$ Sabemos que en 1485 había en la Capilla Real un Villalpando (Cuentas de Gonzalo de Baeza...ob. cit., T. I. p. 97), citado en relación con pagos sobre la adquisición de ornamentos religiosos y litúrgicos para las nuevas iglesias consagradas en Ronda y Marbella. Si bien encontramos pagos de quitaciones para su hermano Francisco, no contamos con las que pudiera recibir Antonio en concepto de capellán real. Por las mismas fechas había otro capellán real de apellido Villalpando, Juan de Villalpando, posible canónigo en León (en 1474, 1478 y 1499, J. $M^{\text {a }}$ SANTAMARTA LUENGOS, $o b$. cit., pp. 78, 80-81) y en Jaén (AGS, $R G S, 10$ de octubre de 1478, fol. 25). Desconocemos el parentesco entre ambos (¿primos?), pero no hay que descartar la existencia de otro miembro de esta familia, clérigo, vinculado con la Casa Real.

${ }^{72}$ AGS. $R G S, 1491-07-20$, fol. 159.

${ }^{73} J o a q u i ́ n$ PÉREZ VILLANUEVA, Bartolomé ESCANDELl BONET (DIRS.), Historia de la Inquisición en España y América, I, Madrid, 1984, pp. 327-328, nota 114 y p. 373. En 1489 figura un "licenciado de Villalpando" como canónigo de Salamanca, pidiendo a la reina amparo en la dignidad de arcediano de Alba (AGS, $R G S, 2$ de junio de 1489, fol. 20).

«Anuario de Estudios Medievales», 35/2 (2005), pp. 605-633 .- ISSN 0066-5061. 
cuenta que la mayoría de sus oficios eclesiásticos estarán orientados al ejercicio de justicia (como veremos, al final de siglo llegó a ser visitador del arzobispado de Toledo).

Las primeras noticias que presentan a Antonio García de Villalpando como doctor proceden ya de la década de los noventa, de su actuación como provisor del obispado de Osma. Su paso por el obispado de Osma estuvo preñado de conflictos con el cabildo catedral que tenía su sede en El Burgo de Osma. Y es que el obispo electo en esa época, un italiano, el cardenal de San Jorge Rafael Sansoni Riario, sobrino del papa Sixto IV, apenas visitó el obispado, por lo que el gobierno de la diócesis, no sólo espiritual, sino también temporal, recayó en su provisor, el doctor de Villalpando ${ }^{74}$. Sería interesante descubrir cómo entró en contacto Villalpando con el cardenal de San Jorge, si directamente, como consecuencia de alguna posible estancia en Roma, o por mediación de los propios reyes, quienes habrían premiado de este modo el regalo del Razonamiento de las Reales Armas, culminado ya por esas fechas. Sea como fuere, el hecho es que Villalpando gobernó en Osma casi como un señor de vasallos, llevado por el enorme poder señorial que ostentaban en Osma y su diócesis los obispos, que tendían a comportarse más como nobles que como religiosos. Esta coyuntura le permitió desarrollar capacidades familiares arraigadas en él: el ejercicio de la jurisdicción y del poder junto a la alta nobleza ${ }^{75}$. El nuevo provisor debió intervenir con mano de hierro ${ }^{76}$ en la ya de por sí alterada vida del cabildo de El Burgo de Osma. Existe documentación que ilustra un grave conflicto en el que no faltó el derramamiento de sangre y la lucha armada en la propia villa. Los miembros del cabildo que impulsaron la resistencia, encabezada por su prior Fernando

${ }^{74}$ En 1489 figura como provisor de Osma por el obispo Rafael Riario Juan de Torquemada, y en 1491 figura ya en su lugar el doctor Antonio García de Villalpando, también por el obispo Riario (Máximo DIAGO, Notas sobre el origen social del clero capitular de El Burgo de Osma y Soria en los siglos XV y XVI, En «Actas de la I Semana de estudios históricos de la Diócesis de Osma-Soria, 1997», Soria, 2000, pp. 50-51).

${ }^{75}$ Máximo Diago ha concluido que las luchas por el poder y el afán de intervención de los obispos en el gobierno de las ciudades de señorío episcopal, tales como El Burgo de Osma, son equiparables con las dinámicas de poder propias del resto de las ciudades, en las que la intervención de la alta nobleza avivaba las rivalidades oligárquicas y las luchas de bandos (Máximo DIAGO, Estructuras de poder en Soria a fiens de la Edad Media, Junta de Castilla y León, 1993, pp. 291-299).

${ }^{76}$ Algunos procesos abiertos en los años 1491-1492: AGS, RGS, 26 de julio de 1491, fol. 112 y 3 de septiembre de 1491, fol. 217, autos ordenados contra el dominico fray Francisco de Aranda, por unos sermones que predicaba con permiso del prior de Peñafiel. El provisor ordenó su prisión cuando se encontraba en plena arenga. Otro proceso, AGS, RGS, 11 de febrero de 1492 , fol. 334. 
Vázquez de Arce (que era, además, capellán real y miembro del Consejo Real) y por el capiscol, Rodrigo de Tablares, reunieron hombres de armas que se encastillaron en la torre de la catedral, desde la cual atacaron el palacio episcopal, sede del gobierno del prior ${ }^{77}$. El motivo de la oposición del cabildo no está del todo claro, aunque Máximo Diago lo relaciona con la propia dinámica política interna del cabildo, reacio a que le impusieran desde el exterior un obispo que no mantuviera lazos con los miembros que lo formaban ni con la nobleza local $^{78}$. Es muy probable que el propio provisor contribuyera a agravar esta situación con su actitud intransigente: la documentación alude a la reforma de costumbres que el provisor quiso imponer al cabildo, y a abusos en el ejercicio de la jurisdicción episcopal ${ }^{79}$. Con el correr de los años, el doctor de Villalpando se vio enfrentado a una oposición similar con el cabildo de Toledo, a propósito de la visita que debía realizar el titular del arzobispado, que por esas fechas era ya el Cardenal Cisneros.

Villalpando estuvo hasta 1493 en el obispado de Osma como provisor, fecha en la que fue nombrado el nuevo obispo, Alfonso de Ulloa y Fonseca. Pero durante otros dos años continúan en el Consejo Real los pleitos que arrastró tras su paso por esta diócesis ${ }^{80}$. Después tenemos unos años de incertidumbre, hasta que aparece propuesto para una canonjía en el cabildo catedral de Toledo, el 7 de mayo de $1498^{81}$. Este nombramiento coincide con la estancia de los reyes en la ciudad, a donde habían acudido a celebrar la jura

\footnotetext{
${ }^{77} \mathrm{Ha}$ estudiado parte de la documentación que se conserva sobre este conflicto, Máximo DIAGO, Estructuras, ob. cit., pp. 297-299. El nombre de pila del provisor aparece equivocado en algún documento, figurando como Alonso y no como Antonio. El resto de la documentación deja claro que el nombre correcto es Antonio y no Alonso. Antonio García de Villalpando acudió al Consejo Real para que instase al prior a pacificar la villa (AGS, RGS, 4 de abril de 1492, fol. 308).

${ }^{78}$ Sobre la “división del obispado”, Máximo DiAGO, ibídem, pp. 293-296.

${ }^{79} \mathrm{El}$ Consejo Real instó al prior y al cabildo de Osma a que no se opusiera a la acción reformadora del provisor (AGS, $R G S, 4$ de abril de 1492, fol. 311). El prior y el capiscol, procesados por el provisor, protestaron a su vez e impulsaron junto con otros canónigos un proceso contra el doctor de Villalpando ante el provisor y vicario general del Cardenal Mendoza (AGS, RGS, 2 de junio de 1492, fol. 185 y 29 de junio de 1492, fol. 279, 27 de julio de 1492, fol. 179).

${ }^{80} \mathrm{AGS}, R G S, 6$ de julio de 1495, fol. 31: el Consejo remite a la Audiencia el pleito con Pedro de Santa Cruz, miembro de la oligarquía soriana. Continúa el pleito con el prior y capiscol de Osma (AGS, RGS, 6 de octubre de 1495, fol. 269 y 31 de diciembre de 1495, AChV, Registro de Ejecutorias, Caj. 93, doc. 31).

${ }^{81}$ Los reyes presentan desde Toledo al doctor Antonio García de Villalpando, siguiendo el breve de Alejandro VI, para la canonjía vacante por la muerte de Francisco Fernández de Cuenca, AGS, $R G S, 7$ de mayo de 1498, fol. 42 . 
como heredera de la princesa Isabel. Se encontraba con ellos el recién nombrado cardenal y arzobispo de Toledo, Francisco Jiménez de Cisneros. Lo más sorprendente es que el doctor Antonio García de Villalpando aparece estrechamente vinculado con él, ostentando el nombramiento de vicario general en el arzobispado de Toledo. El primer cronista del cardenal cuenta cómo Cisneros partió ese año hacia Zaragoza, acompañando a los reyes para la realización de la jura de la heredera en la Corona de Aragón, y dejó como gobernador del arzobispado al doctor de Villalpando ${ }^{82}$. ¿Cómo entró en contacto Villalpando con el cardenal? ¿Fueron los reyes, los que, tras sus conflictivas actuaciones en el obispado de Osma, le buscaron un destino mejor junto al recién nombrado arzobispo y cardenal? Pudiera ser, pero nos inclinamos a relacionar su ascenso con los Velasco, ya que en el consejo del cardenal figuraba como presidente Juan de Velasco, hermano del Condestable. En ese mismo círculo figura el doctor García de Villalpando como conseje$\mathrm{ro}^{83}$. Hay que tener en cuenta que el hijo del contador mayor Sancho García, mantenía un arraigo patrimonial y familiar en Villalpando, por lo que no sería un desconocido para el propio condestable, que era el señor de la villa.

Buena parte de las noticias que se conservan sobre su paso por el arzobispado de Toledo vuelven a presentarnos a un personaje que suscita controversia en el entorno del cabildo. El primero de los conflictos que se generó surge como consecuencia de su nombramiento como canónigo en 1499. El cabildo se opondrá férreamente a dicho nombramiento, hasta el punto de recurrir a Roma en busca de amparo ${ }^{84}$. En cierto modo, el doctor de Villalpando volvía a revivir situaciones problemáticas muy similares que ya habían acontecido en su vida, y no hace falta volver a mencionar los sucesos de Osma. Antes, incluso, de su llegada al obispado de Osma, Villalpando había intentado infructuosamente introducirse en la malla religiosa segoviana, primero como beneficiado de la iglesia de San Martín, sin lograrlo, e

${ }^{82}$ Juan VAllejo, Memorial de la vida de Fray Francisco Jiménez de Cisneros, ed. A. de la Torre, Madrid, 1913, p. 24.

${ }^{83}$ Antonio DE LA TORRE, Servidores de Cisneros, «Hispania», 23/6 (1946), p. 182.

${ }^{84}$ Villalpando consiguió ese año la canonjía y los 250.000 maravedíes de renta, aunque sólo por un año, pues al año siguiente, 1499, le fue arrebatada por Pedro de Carranza con el apoyo de Roma. Sin embargo, en 1501 parece que recuperó la canonjía (Juan MESEGUER FERNÁNDEZ, Relaciones del Cardenal Cisneros con su cabildo catedral, "V Simposio. Toledo Renacentista», Tomo I, primera parte, Toledo, 1980, pp. 64-144).

«Anuario de Estudios Medievales», 35/2 (2005), pp. 605-633 .- ISSN 0066-5061. 
inmediatamente como canónigo del cabildo catedral ${ }^{85}$. Es muy probable que estos antecedentes influyeran en la decisión del cabildo de Toledo de desposeerle de la canonjía, así como el hecho de que Villalpando ostentase la condición de consejero de Cisneros, visitador y vicario general en el arzobispado. Se trataba, sin duda, de un personaje incómodo que representaba el afán de intervencionismo de los prelados en los equilibrios políticos de los cabildos.

Al igual que en Osma, Villalpando se convierte en uno de los gobernadores del arzobispado, debido a la ausencia de Cisneros, que acompañaba a la reina por aquellas fechas. De nuevo su vocación por ejercer el poder (aunque fuera por delegación) no tarda en ponerse de manifiesto en el cumplimiento riguroso de todos los mandatos de Cisneros. Como provisor y vicario general, Villalpando no dudaba en dictar entredichos en defensa de la jurisdicción arzobispal sobre el territorio ${ }^{86}$. En cuanto a la regulación y a la disciplina de la vida del clero, en su labor de visitador del arzobispado de Toledo velaba por el cumplimiento de las constituciones sinodales aprobadas en 1498 en el Sínodo de Talavera y enviaba a su prelado los memoriales oportunos con detalles sobre el estado espiritual y moral de la archidiócesis ${ }^{87}$. En 1499 llevó a cabo una pesquisa en el cabildo cuyos resultados fueron escandalosos (sobre todo en materia de índole sexual) y, poco después, en 1503, fue comisionado por el cardenal-arzobispo para la ejecución de la visita canónica a la diócesis que el mismo Cisneros debería haber realizado personalmente, como todo prelado tras su elevación a la dignidad ${ }^{88}$. La

\footnotetext{
${ }^{85}$ Antonio García de Villalpando reclamó un beneficio en la iglesia de San Martín concedido por muerte de su titular a Pedro de Carboneras, que figura como capellán real (AGS, $R G S, 17$ de agosto de 1490, fol. 272). Al año siguiente, el Consejo Real pide cuentas al deán y al cabildo de Segovia sobre las razones por las que habían desposeído al doctor Antonio García de Villalpando de su canonjía en Segovia (AGS, RGS, 20 de julio de 1491, fol. 159).

${ }^{86}$ En 1502 , la población de Camarena pleiteó con el arzobispo en defensa de su jurisdicción. Desde Sevilla, el 22 de febrero los reyes escriben a Villalpando para que retire el entredicho que pesaba sobre dicha población, en espera de que se resolviera el pleito con el arzobispo que se trataba en el Consejo Real (AGS, CCA, CED- Libros Generales de la Cámara, Lib. 8, doc. 44bis, 1).

${ }^{87}$ José GarCía ORO, El Cardenal Cisneros, II, Madrid, 1993, pp. 45-46.

${ }^{88} \mathrm{El}$ asunto fue lo suficientemente sonado como para que lo recogiera décadas después el cronista y biógrafo del Cardenal Cisneros, Álvar Gómez de Castro. Los comisionados volvieron a apelar a Roma y acudieron a la corte de Medina del Campo, en donde fueron recibidos por los reyes. Se llegó finalmente a un acuerdo y Cisneros se comprometió a realizar él mismo la visita. Analiza detalladamente este conflicto J. MESEGUER FERNÁNDEZ, Relación, art. cit., pp. 66-74 y ss. La documentación básica fue publicada por, Francisco SAN ROMÁN, Cisneros y el cabildo primado al finalizar el año 1503, Toledo, 1919, tirada aparte del «Boletín de la Real Academia

«Anuario de Estudios Medievales», 35/2 (2005), pp. 605-633 .- ISSN 0066-5061.
} 
ejecución de esta visita por una persona ajena al cabildo contó con la oposición de sus miembros más poderosos, entre los que se encontraba el nuncio Francisco de Ortiz. Este conflicto abrió una crisis que afectó a la vida de toda la ciudad, ya que el nuncio, encarcelado junto con otros canónigos por el doctor de Villalpando, dictó sobre ella un entredicho que perturbó la celebración litúrgica de la Navidad ese año. Volvían a repetirse situaciones muy parecidas a las vividas durante el enfrentamiento del doctor Villalpando con el prior de Arce y otros canónigos de El Burgo de Osma, aunque sin llegar al grado de violencia que se vivió en la capital de la diócesis de Osma. Parece, no obstante, que el conflicto llegó a tener suficiente entidad como para que se hablara de "alborotos" y "escándalos": los canónigos comisionados que acudieron a la corte para tratar el asunto con el cardenal reconocen que el doctor de Villalpando estaba siendo maltratado de palabra y de hecho (no en vano el nuncio Francisco de Ortiz le había excomulgado) ${ }^{89}$. Por su parte, Villalpando no se privó de humillar en todo lo posible al nuncio («con gente armada le llevaron por lo más público de la cibdad a la fortaleza de Almonaçir»), hasta el punto de dilatar todo lo posible su excarcelación, a pesar de la firma de concordia que había tenido lugar el día 22 de enero de $1504^{90}$.

Este conflicto en el arzobispado de Toledo, unido a los otros conflictos ya relatados, nos revela una personalidad controvertida, más aliada, dentro de la Iglesia, con los máximos poderes que encarnan los prelados que con los demás canónigos, beneficiados y dignidades colegiados en los cabildos. Villalpando continuó el resto de su vida unido a la persona de Cisneros, ejerciendo no sólo actividades ligadas a sus oficios (a la altura de 1509 ostenta también el nombramiento de capellán mayor de la iglesia catedral de Toledo $)^{91}$, sino también acompañando y apoyando a Cisneros en las

de Bellas Artes y Ciencias Históricas de Toledo», abril de 1919, año II.

${ }^{89}$ Se produjo inevitablemente la intervención real: desde la corte de Medina del Campo se insta al corregidor de Toledo, Pedro de Castilla, a que hiciera uso de la justicia real para apoyar la visita del doctor de Villalpando y del canónigo y capellán real Fernando de Fonseca (AGS, $C C A$, CED- Libros Generales de la Cámara, Lib. 6, doc. 226-1).

${ }^{90}$ Francisco SAN ROMÁN, ibídem, p. 79-85 y 89-95.

${ }^{91}$ Algunas actuaciones de Villalpando se relacionan con supervisiones y control de obras que se hacían en la catedral (información sobre un pasadizo que se construía en 1505 y que enfrentaba a los capellanes de la Capilla de los Reyes y a los de la Capilla de la Reina Catalina (AGS, CCA, CED-Libros Generales de la Cámara, Lib. 7, 87, 1); pagos a Juan de Cuesta por unas vidrieras (R. ZARCO DEL VALLE, Documentos para la Historia de las Bellas Artes, Madrid, 1870, año 1509).

«Anuario de Estudios Medievales», 35/2 (2005), pp. 605-633 .- ISSN 0066-5061. 
empresas personales que asumió este prelado ya que no en vano Cisneros se convirtió a la muerte de la reina en uno de los personajes políticos más relevantes en la Corona de Castilla, como regente y gobernador durante los años siguientes. En su correspondencia, el Cardenal se dirige a Villalpando con un tratamiento que expresa una gran familiaridad, pues le considera «su especial amigo» ${ }^{92}$. Esta fidelidad a Cisneros se tradujo en diversas actuaciones que contribuyeron al engrandecimiento personal del cardenal. En tales actuaciones se pusieron en práctica las dotes intelectuales y la formación universitaria del hijo del contador mayor Sancho García. Una de las mayores preocupaciones de Cisneros por esas fechas era el problema islámico: en una década pasaría de impulsar tareas de evangelización en un contexto especialmente crítico en Granada (persecución de los renegados cristianos, revuelta del Albaicín, conversiones obligadas, rebelión de las Alpujarras), a impulsar la cruzada y la conquista de las tierras islámicas, materializada en la famosa conquista de Orán, en 1509. Para la primera de las estrategias, la de evangelización, Villalpando escribió un tratado, la Instrucción de la vida cristiana, dirigido a los moriscos recién convertidos, cuya impresión fue realizada en Toledo, el año $1500^{93}$. En el episodio de la conquista de Orán, Villalpando (de nuevo gobernador del arzobispado en ausencia del Cardenal) se implicó personalmente y no dejó de animar a los conventos y monasterios a la realización de ceremonias litúrgicas (rogativas, ritos de acción de gracias), pero su labor más importante consistió en conseguir que el cabildo promoviera la impresión de una larga carta que Cisneros le envió relatando pormenorizadamente la "providencial" victoria lograda. La carta fue escrita por el maestro Juan de Cazalla, aunque la intención de Cisneros había sido escribirla de su mano. Una vez recibida, Villalpando la leyó ante el cabildo y propuso su publicación, que finalmente se llevó a efecto ${ }^{94}$. Otros servicios

\footnotetext{
${ }_{92}$ «Carta del señor Cardenal d'España [...] al venerable nuestro espeçial amigo el dotor de Villalpando», ed. $\mathrm{M}^{\mathrm{a}}$ Isabel HERNÁNDEZ, El taller historiográfico: Cartas de Relación de la conquista de Orán (1509) y textos afines, London, 1997, p. 47.

${ }^{93}$ Instrucción de la vida cristiana, compuesta para la de los moriscos nuevamente convertidos, de orden del Cardenal Arzobispo Ximénez, por su visitador general y canónigo de Toledo, el doctor Antonio García de Villalpando, impreso allí por Pedro Hagembach, alemán, a 10 de febrero de 1500. Francisco Méndez vio un ejemplar de este impreso, hoy lamentablemente desaparecido, en la biblioteca de Rafael Floranes (Francisco MÉNDEZ, Tipografía española, Madrid, 1861 , p. 148 y p. 308 ).

${ }^{94} \mathrm{La}$ decisión adoptada se encuentra recogida en el libro de acuerdos del cabildo (Archivo de la Catedral de Toledo -ACT-, Libro de Actos, t. 3, fol. 139). Hay una nueva edición de los textos, a partir de una versión manuscrita ( $\mathrm{M}^{\mathrm{a}}$ Isabel HERNÁNDEZ, El taller historiográfico, pp.
47-54).
}

«Anuario de Estudios Medievales», 35/2 (2005), pp. 605-633 .- ISSN 0066-5061. 
de orden intelectual que prestó Antonio García de Villalpando a Cisneros se relacionan con la organización del colegio universitario de San Ildefonso, fundado por el cardenal. Villalpando participó en la adquisición de volúmenes para la biblioteca de la futura universidad ${ }^{9}$.

El doctor Antonio García de Villalpando murió en 1513 y su muerte quedó reflejada en las actas del cabildo ${ }^{96}$. Algún autor ha mencionado la existencia de su testamento pero aún no lo hemos podido localizar. Hemos hallado, en cambio, otros indicios relativos a su muerte y a su descendencia que nos revelan aspectos de su vida privada que enlazan con sus vínculos familiares y con unas raíces ligadas a su villa natal, Villalpando. El lugar elegido para su enterramiento fue el convento de San Francisco, edificado extramuros de esa villa junto a una de las puertas de la ciudad, convento hoy desaparecido. Los García de Villalpando tenían derechos de patronato sobre este convento y el doctor mandó enterrarse en el arco y capilla principal, junto al altar de la cruz $^{97}$. La noticia es recogida en el testamento de uno de sus hijos, Nuño García de Villalpando, que manda enterrarse en la misma sepultura de su padre, el doctor Antonio García de Villalpando. En dicho testamento, otorgado el año 1531, se recogen varias mandas orientadas a la perpetuación de la memoria de su padre, siguiendo lo ordenado por el mismo doctor en su testamento ${ }^{98}$. No dejan de llamar la atención estas noticias relativas a los hijos procreados por el doctor de Villalpando, aunque se tratara de una circunstancia frecuente y habitual entre el clero de esa época, pero en este caso destaca por ser él mismo uno de los encargados de la represión de tales conductas prohibidas por las constituciones sinodales. El testamento de su hijo Nuño nos aporta el nombre de otros dos de sus hijos: María de

${ }^{95} \mathrm{BNM}$, Ms. 26.056/47. Santiago Aguadé relaciona este inventario manuscrito que se encuentra en la Biblioteca Nacional con el proceso de creación de la biblioteca universitaria (Santiago AGUADÉ NIETO, Relación de Adquisiciones de libros para el Cardenal Cisneros entre 1496 y 1509 . En: «Comercio, mercado y economía en tiempos de la Reina Isabel», Medina del Campo, 2004, pp. 180-181).

${ }^{96} \mathrm{ACT}$, Libro de Actos, t. 4, fol. 54v: el día 10 de agosto de 1513.

${ }^{97}$ RAHB, Ms. 9/4450, $\mathrm{n}^{\circ} 18$, fol. 6r.

${ }^{98}$ «Item, que el cura Juan Calza de la Iglesia de Nuestra Señora Santa María del Templo, cuyo feligrés soy, siga dos treintanarios por el ánima de mi señor el doctor e de los otros defuntos, a quien yo soy en cargo [...] Item mando, de más de las dichas quinientas misas, digan los freires y religiosos de dicho monasterio de San Francisco, tres treintanarios por las ánimas del dicho mi señor, el doctor, y por las otras personas, a quien yo soy en cargo y les den lo acostumbrado». Testamento copiado por Luis CALvo LOZANO, Historia de la Villa de Villalpando, pp. 230-23

«Anuario de Estudios Medievales», 35/2 (2005), pp. 605-633 .- ISSN 0066-5061. 
Villalpando y Mariano García99. Los nombres de los descendientes de sus hijos varones (nietos del doctor) revelan la estrecha relación que les unía a todos ellos con sus orígenes: Nuño tuvo tres hijos llamados Francisco, Antonio y Rodrigo, y Mariano García tuvo, al menos, un hijo llamado Sancho ${ }^{100}$. Los dos hijos del doctor Antonio García estaban avecindados en la villa de Villalpando, en donde el propio doctor poseía parte de sus bienes ${ }^{101}$.

\section{CONCLUSIÓN: \\ MENTALIDAD “HIDALGA” Y CONDICIÓN ECLESIÁSTICA}

A través del repaso que hemos efectuado por los orígenes familiares, la extracción social y profesional de estos dos clérigos, hermanos ambos, podemos comprobar cómo dicha procedencia condiciona en buena medida el "tipo de clérigo" que encarnan. La figura de Antonio García de Villalpando tiene, sin embargo, más matices, como consecuencia de la labor literaria que desempeñó. A grandes rasgos, destaca su ambición y su deseo de acercarse a la corte y de ascender en la carrera eclesiástica por mediación de los reyes, para lo cual se convierte en uno de sus propagandistas. Le intuimos buen predicador, a juzgar por las obras empleadas en la argumentación que sustenta el Razonamiento de las reales armas, y un buen conocedor de los temas favoritos predicados en la capilla real. También dominaba a la perfección la cultura caballeresca que conoció junto a su padre y su tío, pues en esta obra dedicada a los reyes, que puede calificarse como de un "libro de armas moralizado", demuestra unos conocimientos heráldicos impropios de la condición de clérigo. Por otra parte, su identificación con el ideario de los Reyes Católicos es total, revelando en esta etapa juvenil quizá más radicalidad de la que sus propios patronos mantenían por esas fechas. A lo largo de su carrera esa ambición no le abandonó, sino que le llevó a combatir por sus

${ }^{99}$ Luis Calvo Lozano menciona a otro hijo del doctor Antonio García, llamado Gregorio García de Villalpando, a partir de una noticia del Libro de kalendas del Cabildo de SanctiSpiritus», ibídem, pp. 163-164.

${ }^{100}$ Mariano García, vecino de Villalpando, mantuvo durante toda su vida un pleito de hidalguía, que fue continuado por su hijo, Sancho García, fallecido en 1563, y después por el hijo de éste, Antonio García, hasta 1580 (AChV: Sala de Hijosdalgo, Caj. 30, 3).

${ }^{101}$ Antonio de Villalpando, canónigo de Toledo, pleitea en julio de 1509 con Bernardino de Valbuena por la posesión de un molino en Villalpando, AChV, Registro de Ejecutorias, Caj. 238, doc. 36.

«Anuario de Estudios Medievales», 35/2 (2005), pp. 605-633 .- ISSN 0066-5061. 
prebendas y beneficios, disputando todo lo posible con otros clérigos rivales. Su talante estaba más marcado por el espíritu individual que por la solidaridad de grupo, lo que le hacía aliarse siempre con el poder, de ahí que creara suspicacias entre los órganos colegiados de las iglesias por las que pasó. Esta actitud, quizá heredada del hábito familiar de haberse educado entre hidalgos y caballeros que crecieron al amparo de la alta nobleza y del rey, le hicieron, no obstante, prosperar junto al arzobispo de Toledo, el Cardenal Cisneros, cuya confianza supo ganarse. Hemos puesto de relieve sobradamente su formación universitaria, producto también de la tradición letrada de su familia, sostenida por el ejercicio de oficios regios durante varias generaciones. Esa misma tradición familiar le orientó, tanto a él como a su hermano, hacia las tareas judiciales dentro de la Iglesia. No en vano, abuelo, padre y tíos habían ejercido como oidores de la Audiencia real. Las reflexiones sobre la justicia que dirige a los reyes en el Razonamiento apuntaban ya esta preferencia. En suma, podemos identificar a Antonio García de Villalpando como un hombre de Iglesia que comienza a ser habitual en su época o, al menos, es el tipo de clérigo que interesa a la monarquía de los Reyes Católicos ${ }^{102}$, situado en la escala entre las altas dignidades, las cuales seguían siendo anheladas por la alta nobleza, y el bajo clero, todavía poco formado y desconocedor de los mínimos conocimientos litúrgicos y sacramentales. El doctor de Villalpando era un clérigo culto procedente de las filas de la "clase media" de los hidalgos y letrados de la corte, experto, por tanto, en las tareas de gobierno, inflexible y propicio a promover la ortodoxia y la reforma de la Iglesia, pero quizá como una forma de ejercer el poder, más que por convicción espiritual. El mantenimiento de una familia propia con varios hijos en su tierra natal confirma que su futuro estuvo determinado por un designio paterno, por una estrategia familiar más que por una vocación religiosa sincera. Del mismo modo que la mayoría de estos oficiales aspiraban de forma más o menos descarada a que sus hijos ingresaran en las filas de la nobleza (y los García de Villalpando terminarán consiguiéndolo, aunque con el correr de los siglos), tampoco desdeñaban el conseguir para ellos las más altas dignidades dentro de la Iglesia. En este sentido, la trayectoria de Antonio García de Villalpando es comparable a la de otros clérigos cuyos padres

\footnotetext{
${ }^{102} \mathrm{Me}$ remito al estudio de José Manuel NiETo SorIA, Iglesia y génesis del Estado Moderno en Castilla (1369-1480), ob. cit., y a su breves observaciones en José Manuel NIETO SORIA, El clero secular, «El mundo social de Isabel la Católica. La sociedad castellana a finales del siglo XV», Madrid, 2004, pp. 95-111.
} 
también habían sido contadores mayores del rey en tiempos de Juan II o de Enrique IV, tales como Juan Arias Dávila, obispo de Segovia, hijo del contador mayor Diego Arias Dávila, o García Álvarez de Toledo, obispo de Astorga, hijo del contador Alfonso Álvarez de Toledo. Indudablemente el poder alcanzado no fue el mismo, aunque seguramente eran equiparables las ambiciones $^{103}$.

${ }^{103}$ Hay un interrogante sobre la familia García de Villalpando que no ha podido ser esclarecido con los datos conocidos, aunque hay indicios de difícil valoración que precisan de una investigación más exhaustiva sobre esta familia, y es su posible origen judeoconverso.

«Anuario de Estudios Medievales», 35/2 (2005), pp. 605-633 .- ISSN 0066-5061. 